\title{
Urban marginality, religious liminality, and the black poor
}

\begin{tabular}{|c|c|}
\hline \multicolumn{2}{|c|}{$\begin{array}{l}\text { Author: } \\
\text { R. Drew Smith }{ }^{1,2}\end{array}$} \\
\hline \multicolumn{2}{|c|}{$\begin{array}{l}\text { Affiliations: } \\
{ }^{1} \text { Pittsburgh Theological } \\
\text { Seminary, United States }\end{array}$} \\
\hline \multicolumn{2}{|c|}{$\begin{array}{l}{ }^{2} \text { Department of Philosophy } \\
\text { and Systematic Theology, } \\
\text { University of South Africa, } \\
\text { South Africa }\end{array}$} \\
\hline \multicolumn{2}{|c|}{$\begin{array}{l}\text { Note: } \\
\text { Prof. Drew Smith is Professor } \\
\text { Extraordinarius in the } \\
\text { Department of Philosophy } \\
\text { and Systematic Theology } \\
\text { at the University of } \\
\text { South Africa, South Africa. }\end{array}$} \\
\hline \multicolumn{2}{|c|}{$\begin{array}{l}\text { Correspondence to: } \\
\text { R. Drew Smith }\end{array}$} \\
\hline \multicolumn{2}{|c|}{$\begin{array}{l}\text { Email: } \\
\text { rsmith@pts.edu }\end{array}$} \\
\hline \multicolumn{2}{|c|}{$\begin{array}{l}\text { Postal address: } \\
\text { Pittsburgh Theological } \\
\text { Seminary, } 616 \text { N. Highla } \\
\text { Avenue, Pittsburgh, PA } \\
\text { 15206, United States }\end{array}$} \\
\hline \multicolumn{2}{|c|}{$\begin{array}{l}\text { Dates: } \\
\text { Received: } 24 \text { June } 2015 \\
\text { Accepted: } 10 \text { July } 2015 \\
\text { Published: } 25 \text { Nov. } 2015\end{array}$} \\
\hline \multicolumn{2}{|c|}{$\begin{array}{l}\text { How to cite this article: } \\
\text { Smith, R.D., 2015, 'Urban } \\
\text { marginality, religious } \\
\text { liminality, and the black } \\
\text { poor', HTS Teologiese } \\
\text { Studies/Theological Studies } \\
71(3) \text {, Art. \#3079, } 8 \text { pages. } \\
\text { http://dx.doi.org/10.4102/ } \\
\text { hts.v71i3.3079 }\end{array}$} \\
\hline \multicolumn{2}{|c|}{$\begin{array}{l}\text { Copyright: } \\
\text { (C) 2015. The Authors. } \\
\text { Licensee: AOSIS } \\
\text { OpenJournals. This wor } \\
\text { licensed under the Crea } \\
\text { Commons Attribution } \\
\text { License. }\end{array}$} \\
\hline \multicolumn{2}{|l|}{ Read online: } \\
\hline 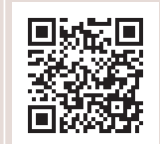 & $\begin{array}{l}\text { Scan this QR } \\
\text { code with your } \\
\text { smart phone or } \\
\text { mobile device } \\
\text { to read online. }\end{array}$ \\
\hline
\end{tabular}

While many persons within westernised or westernising nations such as the United States of America and South Africa continue to place importance on matters of faith, a growing number of those persons approach matters of faith informally rather than formally and individually rather than institutionally. The implications of this are that among 21st century populations informal religious formation may be as important as or more important than the formation taking place via formal religious channels. A central emphasis of this article is that this is especially true among more socially marginalised populations, not simply because they may not enjoy the same level of access to formal institutions, but also because they may regard those institutions as spiritually and culturally restrictive and exclusionary. The contributions of the article are, firstly, its use of original and unique survey data generated from neighbourhood studies the author directed in low-income contexts within several US cities and within Pretoria, South Africa, and, secondly, its analysis of informal ways the urban poor engage Christian ideas and practices - an aspect of urban religion that has not received adequate scholarly attention.

\section{Introduction}

As many global North countries experienced steady and sometimes dramatic declines in formal religious involvement during the past 50 years or more, high levels of formal religious involvement persisted in the United States throughout much of the 20th century in defiance of the tide of secularism overtaking Europe. This persistent US religiosity ran counter as well to mid-20th century predictions by American scholars and pundits that the United States would also soon succumb to secular forces overtaking other westernised or westernising nations (Cox 1965). But just as the secularisation thesis was being declared officially irrelevant to the United States due to the persistently high percentages of Americans indicating strong religious affinities (more than 90\% religious affiliation until the 1990s), ${ }^{1}$ there have been a series of sometimes subtle and sometimes conspicuous indicators countering the prevailing triumph-of-religionin-America narrative. In the last several decades, formal religious affiliation has been declining more noticeably within the United States as evidenced by diminished church attendance and memberships, an increasing number of church consolidations and closings, and a growing number of persons who indicate having no religious preference or affiliation.

The signs of declining religious affiliation among America's urban poor have been obvious since the 1960s (as the urban poor became more geographically concentrated, culturally isolated, and pushed to the margins of social and institutional life), but those trends proved largely insufficient within mainstream opinion streams as reasons to shift the 'American religiosity' narrative. More recently, however, national surveys have shown notable declines in religious affiliation among Americans in general and, while it is not clear whether these figures reflect more systematic inclusion of the urban poor in their counting procedures, it is clear they capture declines among younger and more highly educated persons. According to a 2015 national survey by Pew Forum, $23 \%$ of Americans over 18 years of age indicated having no religious affiliation, an increase of seven percentage points since a similar Pew Forum survey in 2009. The percentage of Americans indicating no religious affiliation in a 1990 survey was only 8\%, which means that from 1990 to 2015 the percentage of religiously non-affiliated Americans has tripled (Pew Forum 2015).

This national data on religious affiliation among Americans points to a more complex narrative about American religious life than captured in either the persistent religiosity thesis or in the encroaching secularisation thesis. A more accurate description of American religious life is that while the vast majority of Americans continue to place importance on matters of faith, a growing number of those persons approach matters of faith informally rather than formally and individually rather than institutionally (Pew Forum 2015). The implications of this, even

1. See Stark and Finke (2000:79); see also Stark (1999:270). 
for contexts beyond the United States (and whether or not within those contexts formal and institutional affiliation have remained strong) are that among 21st century populations informal religious formation may be as important as or more important than the formation taking place via formal religious channels.

A central emphasis of this article is that this is especially true among more socially marginalised populations, not simply because they may not enjoy the same level of access to formal institutions but also because they may regard those institutions as spiritually and culturally restrictive and exclusionary (Kunreuther \& Covington 2006). This premise is examined here in the light of survey and interview data gathered from residents living in very low-income, densely populated neighbourhoods in four US cities and in Pretoria, South Africa. The populations within each of these neighbourhoods are not only extremely poor but they are also largely transient - driven from place to place through evictions for infractions (such as failure to pay), dislocations resulting from urban development schemes, or migratory pursuits of new opportunities (as in the case of migrants from other locales, or immigrants from other countries). Urban South Africa and urban America are also places characterised by some of the highest rates of wealth inequality in the world, ${ }^{2}$ and these wealth inequalities and their correspondence with race also impact the prospects for interactions between churches and residents in these central city research neighbourhoods where congregations may tend to be more prosperous than the transient populations within the neighbourhoods.

This article also argues that the 'informal' aspect of 'informal religious formation' can refer not only to formational activities taking place apart from formal religious institutions, but refer as well to the experience of persons involved in formal religious institutions where there is minimal integration between the religious life of the institution and the personal affairs of the participant. In these instances, as discussed below, religious participants may pass through religious institutions temporarily and superficially without the individual or the institution being affected by the encounter in deep or enduring ways. This dynamic is evidenced increasingly (though not exclusively) within 21st century transitory urban life, especially as embodied in the internal dislocations of the urban poor and the geographical instabilities of migrating and immigrating populations.

Although these dynamics take on added urgency amidst sharpening 21st century economic disparities within contexts such as the United States and South Africa, these dynamics are hardly new, as poignantly illustrated in the Acts 16 account of the ministerial interventions and encounters of the apostle Paul within 1st century Macedonia. The article

2.According to Credit Suisse's 'Global Wealth Report 2013', the United States ranks 4th in the world for wealth inequality and South Africa ranks 11th; viewed 01 June 2015 , in the world for wealth inequality and South Africa ranks 11th; viewed 01 June 2015,
from https://publications.credit-suisse.com/tasks/render/file/?fileID=BCDB1364A105-0560-1332EC9100FF5C83. provides an exposition of this biblical passage, drawing on the positioning of marginalised women in the passage and Paul's ministerial re-positioning in response to these women as metaphor and guide for 21st century ministry at the social margins.

\section{Recalling informal formative contours of sacred religious pasts}

In Acts 16, Paul receives a night time vision in which a man from far-off Macedonia beckons him to come provide assistance in some undesignated matter. Paul and his associate Silas immediately depart for Macedonia, a large region between the Greek peninsula and the Balkan highlands that was a seat of imperial power prior to being conquered by Rome in 146 BCE. The Acts passage does not suggest Paul received any specific instructions in his vision about where to go within this large region, and for reasons that remain unclear Paul goes to the Macedonian city of Philippi. Philippi was considered to be the most prestigious city in Macedonia, in part perhaps because it was the city in Macedonia most like Rome its colonial master. It was a place of high culture where many elites from the Macedonian region lived, and it was the kind of place toward which Paul might gravitate as a noted scholar accustomed to moving in circles of influence and as an evangelist with an already established pattern of ministering within urban centres across Asia Minor.

After arriving in Philippi, Paul and Silas went to the synagogue, the gathering place for Jewish religious and community leaders, and spent several days interacting within that context. But by locating within the cultural centre - among men of influence, in an empowered religious institution, within a prestigious city - Paul was unable to receive confirmation of the urgencies conveyed in the vision he received. So the passage indicates that on the Sabbath (the high holy day), Paul and Silas were inspired to leave the synagogue and go outside the city to a riverside where several women were having a prayer meeting. Hence, rather than taking their place in worship within the halls of male privilege and power, Paul and Silas were led to worship and fellowship with a few women of humble circumstances in a hidden-away outdoor service. Seemingly, what Paul and Silas discovered was there are voices and stories missing from the cultural and religious centre that are accessed only once we move to the margins.

Women most certainly resided at the margins of ancient Jewish societies. They had virtually no authority or rights outside the home and, even within the home, girls were under the control of their father until sold for dowry to their husbands who then assumed control. Women were not to be greeted in the streets, they were to walk six paces behind their husbands, and they could not receive inheritances. Formal opportunities for instruction in the law or religious teachings were severely restricted for women, and they operated only at the periphery of synagogue and temple life. Within this context, the public assembling of a few 
women for prayer - even if largely out of sight upon the banks of a river - was undoubtedly a radical act. Faith formations at the social margins are often subversive in this sort of way.

A similarly constricted and subjugatory intent was evident as well in the early exposures of American slaves to Christianity in the 18th and 19th-century American Slave South. Although the Christian instruction of slaves was initially forbidden in the American South, slaves gained exposure to Christian teachings sometimes covertly, including by secretly listening-in on white Christian gatherings, but also in some instances through direct instruction from a gradually increasing number of white Christians (emanating from the South and the North) who thought it important that slaves be Christianised. Where whites supported Christianising slaves, it was sometimes motivated by religious concerns, but often by a political concern with reinforcing the subjugated status of slaves through frequent rehearsals of scriptures calling for obedience to authorities.

Despite the subjugatory emphasis prevalent within the Christianity slaves encountered through authorised white channels, black slaves frequently saw beyond these ideologised uses of Christianity to the deeper and more liberative potentialities of Christianity. It was this more spiritually and socially liberative potential of the faith slaves pursued - secretly and on their own terms. As historian Albert Raboteau documents, slaves would 'steal away' to the woods at night for worship gatherings that were more consistent in style and content with the existential experiences and eschatological yearnings of slaves - all the while careful to avoid discovery by slaveholders of these 'hush harbor' churches (Raboteau 1978:111). In this sense, slaves lived between two expressions of Christianity, says Raboteau (1978:112): '[I]nstitutional and noninstitutional, visible and invisible, formally organised and spontaneously adapted.'

In a closely related sense, colonial-era encounters between Africans on the African continent and the Christianity of European missionaries produced authorised and unauthorised trajectories of African Christian expression. Emanating from African exposures to missionary renderings of a Christianity often closely allied with colonial aims, African Christianity embodied a kind of toleration of impositional aspects of European Christianity while also finding religious affinities with the more salutary and liberative possibilities inherent within Christian teachings, including Christianity's conceptual support for ideals of freedom and self-determination. Another close parallel here to American slave Christianity included the need for this biblically validated defiance on the part of colonised Africans 'to remain concealed and coded' (Comaroff 1985:2). Like the hush harbour religious gatherings of American slaves, or the plaintive Spirituals sung by slaves in which religious phraseologies could double as messages of social resistance, black South Africans also appropriated Christianity in ways removed and hidden from the gaze and control of European authority (Fields 1985).

A common thread then between American slaves and colonised Africans in the encounter with European Christianity was the liminality of that experience - the state of being in-between Christianity's liberative and subjugatory possibilities. Commenting on the South African context, anthropologist Jean Comaroff observes that black South African encounters with colonial-era European Christianity produced a black social and conceptual redefinition in response to European assaults on these realms that 'created a middle ground between a displaced "traditional" order and a modern world whose vitality was both elusive and estranging' (Comaroff 1985:253-254). While being poised between tradition and modernity was indeed a critical middle grounding in the lives of subjugated blacks. Raboteau draws attention to a crucial theological in-betweenness in the experience of American slaves. Living between 'present pain and future relief', slaves 'imagined their lives in the context of a different future', says Raboteau, including 'a future reversal of the conditions of whites and blacks' in keeping with God's mandated justice and retribution (Raboteau 1978:218, 290-291).

These historical illustrations of black religious inbetweenness suggest ways Christian content can be embraced without embracing fully or at all the ideological and institutional packaging of that Gospel - and this is a dynamic transcending black encounters with white Christianity. There is a similar dynamic operative, in fact, among a growing number of persons who say they are religiously unaffiliated, yet profess Christian beliefs and (informally) pursue Christian devotional practices - a trend sometimes referred to within contemporary parlance as being 'spiritual but not religious' (Fuller 2001). According to recent US survey data, one-third of religiously unaffiliated American adults characterise themselves as 'spiritual' but not 'religious', with Americans born between the early1980s and early-2000s (the so-called 'millennial' generation) especially likely to characterise themselves in this way (Pew Research Center 2012).

Liminal encounters with Christianity - this embrace of precepts but not packaging, of ideals but not forms is descriptive of ways black urban poor populations sometimes experience Christianity. As demonstrated below, this has been the case where low-income urban Americans who have had little or no interaction with churches have nonetheless placed a high priority on their personal religious devotional life. This can be seen as well where the urban poor, both in the United States and South Africa, have enjoyed some level of formal interaction with congregations, but in ways that proved quite selective and utilitarian. In these cases, low-income participants acquired what they could of spiritual or social value from the interactions without ever fully entering into the community of congregants or subjecting themselves to its authority or broader influences. 


\section{Formal and informal religious formation at contemporary urban social margins}

When something achieves institutional status, it takes on a formalised, established, even permanent character, and it is within this paradigm that contemporary Christianity operates in most instances, or at least it is a paradigm toward which it largely aspires. Approximately one-third of the world's population identifies as Christian, and the vast majority of that Christianity is channelled through denominational, interdenominational, or congregational institutional frameworks, or through church-related civil society institutions such as schools, hospitals, or social service organisations. Christianity, like much of social life in westernised social contexts, plays out upon a highly institutionalised landscape.

Nevertheless, despite the expanded reach of institutions within societies, scholars from many disciplinary vantage points have documented post-institutional tendencies within contemporary life, noting the loosening grip of institutions ranging from governmental institutions, to civic and educational institutions, to religious institutions (Bibby 1987:10-18; Mamdani 1996; Roozen \& Nieman 2005; Sennett 1992; Wuthnow 1990). It has been a movement away from form to formlessness, away from permanence to impermanence, away from rootedness to rootlessness. With respect to the black urban poor, this also may be connected to deeper disaffections growing out of longstanding race-based and class-based social antagonisms operative within grossly unequal and highly racialised societies, such as the United States and South Africa (Chubb \& Van Dijk 2001; Smith 1998; Swartz, Hamilton Harding \& De Lannoy 2013; West 1993). Moreover, ethnicity and national origin serve as markers of social difference that may also potentially translate into social marginalisation and distance within urban spaces, especially where these are impoverished population groups as they are in the cases of the predominantly black neighbourhoods that are part of the present study (Bouillon 1998; Card \& Raphael 2013; Maharaj 2009; Wacquant \& Wilson 1989). Within South African urban contexts, an added dimension of social marginalisation has been that many persons bearing markers of difference related to ethnicity and national origin may also hail from rural contexts from within South Africa or other sub-Saharan African countries. As Mahmood Mamdani points out, urban-rural divisions within colonial or postcolonial African contexts have not been easily bridged in efforts by central authority structures (whether city-level or national-level authority) to establish unity across these social boundaries (Mamdani 1996).

Nonetheless, governmental and civil society institutions (including churches) have routinely attempted to construct normative bridges within black urban poor spaces across not only urban-rural divisions but also racial, ethnic, and class divisions more broadly - although often without great success (Hyden 1980; Mays \& Nicholson 1933; Nafziger 1988;
Resnick 2013; Smith 2003). Increasingly within contemporary urban contexts, churches and faith-based institutions have been looked to as strategic resources for community bridgebuilding due to their geographic positioning on the front lines of impoverished neighbourhoods in which public authorities have proven unwilling or unable to systematically invest (Burchardt 2013; Chaves \& Tsitsos 2001; Cnaan \& Boddie 2001). Despite a greater social services emphasis by urban churches (and the more favourable humanitarian light in which these churches are potentially cast as a result), many urban congregations especially in the poorest neighbourhoods appear to be quantitatively and qualitatively weakening as sources of community (Smith 2003).

Having said this, the vast infusions of organisational life, dynamism, and energy into global Christianity from global South Christians would seem to contradict post-institutional characterisations, at least as related to an overall assessment of church life. But as the experiences of the stationary and migratory poor in urban America and urban South Africa make clear, institutional church life may be of far less importance to Christian formation and religious communitybuilding among the poor than the formational steps they take from their own spaces and on their own terms. I explore this through research I conducted via two empirical projects: a four-city study of interactions between churches and the poor in US neighbourhoods; and a study of interactions between churches and recently-arrived migrants and immigrants in the Sunnyside neighbourhood of Pretoria, South Africa.

\section{Churches and the urban poor in four cities in the United States}

American social pundits, policy-makers, and even religious leaders, when capturing the poor within their gaze at all, have placed considerable emphasis on character formation, generally attributing the poor with significant deficiencies and distortions in this area (Ramphele 1992; Wilson 1987). The assessment has tended to be that the urban poor are not much involved with church life or much concerned with matters of spiritual development. Survey and interview research I conducted in low-income neighbourhoods in four US cities proves the former assumption to be largely correct and the latter assumption to be largely incorrect (Smith 2001, 2003).

The four cities where the study took place were Camden, New Jersey; Hartford, Connecticut; Indianapolis, Indiana; and Denver, Colorado - cities that varied by size, overall demographics, and region of the country. The research neighbourhoods were predominantly African-American, although a number of the research neighbourhoods contained sizeable white and Latino low-income populations as well. Researchers conducted a door-to-door survey in two or more low-income housing complexes in each of the four cities. The surveys yielded responses from 1206 residents about their interactions with local congregations and about their involvement in other aspects of community life. Researchers also conducted telephone 
interviews with churches within one mile of the housing complexes, asking official representatives of 136 churches about their community outreach initiatives and other aspects of their congregational ministries. Nine out of ten church respondents were clergy. ${ }^{3}$

The survey and interview research showed that churches, although a significant institutional presence in most urban communities and an important spiritual and social resource for some low-income families, have had limited impact on the lives of families living in the poorest urban neighbourhoods. This was demonstrated to have resulted, in part, from limited interaction between congregations and their low-income neighbours - an observation amplifying related scholarly findings on this matter (Cnaan \& Boddie 2001; Laudarji \& Livezey 2000; Wacquant \& Wilson 1989; Wilson 1987). What this makes clear is that physical proximity between congregations and the urban poor is not necessarily a sufficient basis for meaningful interaction and engagement between the two.

Among the evidence of weak connections between congregations and residents in these neighbourhoods was that two-thirds of the survey respondents indicated they were not members of any religious congregation, and roughly the same percentage indicated they had not attended religious services at a congregation more than a few times the previous year. Approximately two-thirds of the respondents also stated they had not been contacted by churches through any means the previous year. Even where respondents had participated at some level in religious worship activities or in a church-based social service program, the respondents appear not to have formed strong connections with the congregation or developed a sense of community with fellow churchgoers - due both to the low frequency of participation by these residents in congregation-based activities and to the low interpersonal and relational level of those interactions.

Relationship-building and community-building possibilities were impeded in these contexts by cultural barriers between low-income populations and what were largely workingclass and middle-class congregants - with low-income residents expressing a lack of comfort interacting with congregants whose expectations pertaining to church attire, cultural bearings, institutional protocols, and religious pieties might be hard for residents to satisfy. Substantive interactions between low-income residents and congregants were also impeded by the often transient quality of residential life in these low-income neighbourhoods. Almost 70\% of the residents had lived at their present address 5 years or less, $59 \%$ actually lived at their current address 3 years or less, and $23 \%$ had lived at their address 1 year or less. The fact that so many of the residents had not lived in these neighbourhoods long was suggestive as well that they may not remain there for long either.

3. Housing complex residents surveyed included 401 in Denver, 401 in Indianapolis, 225 in Camden, and 179 in Hartford. Churches surveyed included 40 in Indianapolis, 33 in Denver, 33 in Hartford, and 30 in Camden.
Low-income residents relocate for a variety of personal reasons, but they are sometimes forced to relocate en masse as a result of governmental public housing policies. This was the case for residents at several of the public housing complexes in Denver and Indianapolis, whose complexes were targeted by a public housing policy initiative called Hope VI aimed at de-concentrating urban poverty by demolishing low-income housing complexes and replacing them (sometimes) with mixed-income housing. Whether or not mixed-income housing was actually built in place of the demolished low-income housing, the residents of the lowincome housing complexes were dispersed during the process and only occasionally able to return to these neighbourhoods as occupants of any newly constructed mixed-income housing. This residential transience decidedly reduces resident prospects for long-term relationship-building and community connections within these neighbourhoods, including aspects bearing on church life.

Residential impermanence and cultural incompatibilities with church life represent two of the more prominent reasons low-income residents who pursue involvement with congregations may achieve little more than a cursory relationship with their respective congregation. As a result, these congregations tend to serve as temporary church homes at best, but more often simply as stop-over or passthrough activities. Low-income residents may derive lasting spiritual resources from these interactions, but far less may result of enduring social or cultural bridge-building value for these individuals or institutions.

An equally important finding of the four-city study is that limitations impacting low-income residents' religious formation via formal channels are countered by informal steps residents take on their own behalf to facilitate their religious formation. For example, $73 \%$ of low-income residents said they felt it was important they spend time in prayer, with $57 \%$ indicating they actually pray every day, and another $8 \%$ stating they pray at least once per week. When asked about their habits related to reading the Bible, $64 \%$ of the residents said they felt it was important they read the Bible on a regular basis, with $16 \%$ indicating they actually read the Bible every day, and another $15 \%$ stating they read it at least once a week. Residents were also asked whether they watch religious television programs or listen to religious radio programs and $42 \%$ indicated they turned to such programs, with $10 \%$ stating they turn to these religious programs at least once a day, and another $17 \%$ stating they turn to these programs at least once a week. ${ }^{4}$

Contrary then to presumptions of widespread religious disinterest and disinclination among the urban poor, this data reveals instead that the urban poor are strongly disposed toward spiritual matters but weakly committed (in theory and

4.Data from the Pew Forum's 2015 American Religious Landscape Survey provides similar findings about the importance of informal processes of religious formation similar findings about the impotance of informal processes of religious formation in instances where religious formation is not necessarily being pursued via forma channels. At least with respect to the data specifically on African Americans who are not affiliated with any religious group, the Pew data shows that $48 \%$ of these unaffiliated African Americans pray daily. See Pew Forum (2009). 
in practice) to formal church institutions as effective contexts in which to pursue these spiritual interests and inclinations. Instead, the urban poor are more likely to pursue spiritual formation through more readily available and personally facilitated means.

\section{Churches and urban migrants and immigrants in Sunnyside, Pretoria}

Urban South Africa provides an important comparative window on the relationship between social and religious transience and ways formal religious formation is supplemented and countered by informal religious formation. Survey and interview research I conducted in Sunnyside, a central Pretoria neighbourhood, sheds light on this dynamic through the experience of newly arriving black and mostly impoverished migrants and immigrants within what had been a historically white, working-class context of residential and congregational life.

Sunnyside, a roughly four kilometre area comprised mainly of high-rise apartment flats and approximately $30 \quad 000$ residents, is one of six neighbourhoods located in the area referred to as Pretoria Central. ${ }^{5}$ Sunnyside has been a gateway neighbourhood where civil servants and tertiary students have resided (primarily whites until recently) while pursuing governmental jobs or tertiary studies at the University of Pretoria or University of South Africa. Once these residents became more economically mobile, secured employment elsewhere, or ended their studies, they frequently relocated to other neighbourhoods. Nevertheless, the neighbourhood maintained its predominantly white, largely Afrikaans-speaking character until South Africa's democratic transformation was well underway in the early 1990s. Since the early 1990s, Pretoria Central neighbourhoods have undergone as rapid and extensive a demographic transformation as any place within post-apartheid South Africa. Migrants from across the country relocated there from rural areas and from black and coloured townships, and there has also been a post-apartheid immigrant influx from other African countries. In 1996, the white population within the ward comprising most of Sunnyside was 15 230, while the black population numbered 4432. By 2001, the white population had declined to 9009 and the black population had increased to 16125 .

These recent neighbourhood in-migrations and outmigrations are part of the generally transient nature of post-apartheid South African life, characterised as it is by institutional and organisational flux and a physical and cultural unsettledness. In large numbers, beginning in the early 1990s, blacks began moving into higher income neighbourhoods from which they were once excluded, whites began seeking neighbourhoods further removed from central urban areas or else moving out of South Africa altogether, and black migrants and immigrants from elsewhere in

5.Pretoria Central includes the Arcadia, Clydesdale, Hatfield, Marabastad, Sunnyside, and Pretoria Central Business District neighbourhoods. This area conforms to parts
of what were electoral wards 56,58,59, and 60 (as of the 2001 Census), but what as of 2011 are electoral wards 56, 58, 59, 60, 80, 81, and 92 . the country and elsewhere on the continent began arriving in urban core neighbourhoods such as Sunnyside. This movement was captured in 1996 Census data which showed approximately $59 \%$ of South African-born persons ages 20-55 had migrated to their residential district (Zuberi \& Sibanda 2005:267).

This amount of residential flux and unsettledness no doubt poses significant challenges to an effective process of community formation and belongingness, especially in a national context where there have been such strong legacies of resistance to social and geographic boundary-crossing. One observer, Simone (2001), framed the challenge this way:

An interesting question is how these cities are perceived by the migrants ... The processes creating different perceptions are complex. It is partially a function of the different possibilities the migrant has in the city in question. It can also be related to the density of his/her links with fellow nationals in the new city. This will have a major impact on whether the migrant feels at home or a perpetual stranger and whether the move is a permanent or a short-term one. (p. 164)

Certainly, as the resident population of neighbourhoods such as Sunnyside changed during the 1990s, its community life and institutions (including its churches) were also transformed. It therefore is important to ask whether this resulted in communities and institutions that gained new strength and vitality as a result of culturally diverse population influxes, or whether these in-migrations (and out-migrations) resulted in a weakening and fragmenting of these institutions and communities.

In exploring these matters, I conducted research in 2005 in which I interviewed pastors of nine of Sunnyside's ten well established congregations, and surveyed 975 worshippers from eight of those congregations. Eight of the nine congregations were founded in the 1970s or earlier (with half of those founded in the 1940s or earlier). Although the racial composition of these longstanding congregations transitioned from predominantly (if not exclusively) white to predominantly persons of colour, as of 2005 the denominational identity, doctrinal priorities, and (often) leadership teams within the congregations had remained the same in most instances. Six of the congregations had white pastors, four of which had served in that capacity 6 years or more. Two of the congregations had 'coloured' pastors who had served 5 years or less. The approach several of these congregations had taken in attempting to maintain their historical identity while accommodating their new demographic realities had been to facilitate parallel congregations via multiple worship services each Sunday. Typically this meant holding an early-morning service that maintained continuity with the congregation's historic worship culture and constituency - which is to say a service that conformed liturgically and linguistically to mostly elderly, white, Afrikaans-speaking or English-speaking members. A second service later in the morning was often contemporary in worship style, youthful in orientation, and conducted in 
English (often interspersed with African languages). The primary continuity between the two worship contexts was that the white pastor generally presided over both services.

The surveys were conducted during the English-speaking services of the respective congregations, which meant the respondents tended to be recent migrant and immigrant arrivals to the neighbourhood. Only $8 \%$ of these respondents had lived in the neighbourhood longer than 10 years, with another $10 \%$ indicating residency in the neighbourhood between six and 10 years. A full $40 \%$ of the respondents had lived in the neighbourhood less than a year, and another $26 \%$ had lived there between one and 3 years. Also, two-thirds of the respondents said they lived two kilometres or less from the congregation they were attending, while only $14 \%$ lived more than 10 kilometres from their respective congregation. In fact, very few of these recently-arrived migrants or immigrants possessed vehicles, so it is understandable that those interested in attending church would choose a congregation within walking distance.

Attempting to integrate black migrants and immigrants into previously white congregations through separate worship tracks for distinct constituencies certainly facilitated black-white coexistence within these newly diversifying congregational contexts, but this did not necessarily translate into a sense of community and relationality across racial and ethnic boundaries. The distinct worshipping constituencies seemed weakly connected to one another, and within several of the congregations where the leadership and authority structures remained under white control, the congregation appeared weakly connected institutionally to its now predominantly black neighbourhood environs, and the black worshippers within these congregations appeared weakly connected to the institutional life of the congregation beyond the worship experience.

These congregations seemed to function as pass-through worship experiences for many of these black migrants and immigrants, where they were content to gather for worship on Sunday morning (and felt very welcomed in doing so), but where relatively little was gained in some instances from their congregational involvement that provided them with social footing and social structuring of their lives beyond Sunday worship. There is certainly some urgency to assisting persons with gaining social footing within a national context characterised by large numbers of refugees and asylum seekers (153 300 in 2012 according to UNHCR) and a considerably larger number of undocumented immigrants (2-8 million in 1996 by South African Police estimates and possibly as many as 12 million in 2004 according to Seafarers Assistance Program). This population would not be able to exercise a vote within South African elections and would be positioned even less favourably than most South African citizens already are in efforts for acquiring limited employment opportunities or bursary support for tertiary studies.

Responses to the Sunnyside congregational survey make clear the relative disconnectedness of Sunnyside's largely migrant and immigrant population from South African mainstream culture and institutions - and the disconnectedness of the congregational ministries from the social needs of these parishioners. First of all, only $46 \%$ of these churchgoers were employed, and $33 \%$ of these survey respondents indicated having no income whatsoever. Another $8 \%$ earned less than 20000 rand (or 3300 dollars at 2005 exchange rates). But when asked how helpful their congregation had been in assisting them with job skill training and employment matters, only $22 \%$ of the respondents considered their congregation as having been 'very helpful'. Additionally, although the large immigrant populations would be especially susceptible to isolation from South African civic affairs given their voter ineligibility and potential estrangement from local and national political life, only $34 \%$ of the respondents felt their congregation had been very helpful in encouraging civic participation and only $43 \%$ said the congregation was very helpful in encouraging awareness about national current events.

Although these congregations serve as anchor institutions within the Sunnyside neighbourhood (at least in the sense of their enduring institutional and religious presence), they have not provided especially strong social anchoring within a local context where so many of the new residents hail from and retain strong connections to far-away contexts, and where the encounters and intersections between the cultural worlds of Sunnyside's residents and local congregations are not as organic or compatible as those existing within the context prior to the transitions of the 1990s. This engagement between congregations and newly arriving residents reflect an increasing breadth, but not necessarily depth, with residents and congregations coming together on Sunday mornings in vibrant worship portrayals of cultural pluralism. Nevertheless, migrant and immigrant residents in large numbers will pass through Sunnyside congregations on Sunday mornings, perhaps for several years, then likely move on to new contexts or to the one from which they came - often without any acknowledgement from their host congregation that they were ever there, or that it even mattered they were there (beyond the optics).

This is not to suggest these encounters did not provide significant benefits to the migrants and immigrants moving through these congregational contexts. The Sunday worship experiences served as religious and cultural wells from which migrants and immigrants drank deeply, although often in the kind of impersonal and disconnected way persons viewing religious television programs or listening to religious radio programs drink from those wells. Congregational platforms, in the same sense as television and radio platforms, serve simply as delivery vehicles to which there is a momentary and primarily utilitarian connection and toward which migrants and immigrants hold no longer-term attachment than many of these congregations appear to hold toward them as a population of worshippers. In short, the encounter and interaction between many of these congregations and worshippers lacks formalisation - it remains informal. 


\section{Concluding thoughts}

Self-determined and informal approaches to religious formation feature prominently within contemporary Christianity - as illustrated in the experiences of the black poor in Sunnyside and in the four US cities. But this also points to a broadening stream within western Christianity in general, increasingly characterised by a consumerist approach to church engagement. Churchgoers constantly shop for the next best iteration in Christian worship and programming and concern themselves decreasingly with congregational life as a source of community to which they might belong or as a pathway into community affairs beyond church walls. Nevertheless, in this growing tendency to uncouple faith formation from formal faith structures, at least one conclusion that can be reached about situations where faith formation takes place separately from formal church structures (as in the case of nonchurchgoing Christians seeking God in their own way) is that there can be all kinds of encounters between people and the Gospel that are not impeded by church walls and boundaries. The vibrant religious expressions that formed in contexts of enslavement, colonial subjugation, contemporary urban margins, or by a Macedonian riverside eloquently attest to the power and significance of informal religious formation.

\section{Acknowledgements Competing interests}

The author declares that he has no financial or personal relationships which may have inappropriately influenced him in writing this article.

\section{References}

Bibby, J., 1987, Politics, parties, and elections in America, Nelson-Hall, Chicago, IL. Bouillon, A., 1998, 'New' African immigration to South Africa, Casas, Cape Town.

Burchardt, M., 2013, 'Faith-based humanitarianism: Organizational change and everyday meanings in South Africa', Sociology of Religion 74(1), 30-55. http:// dx.doi.org/10.1093/socrel/srs068

Card, D. \& Raphael, S. (eds.), 2013, Immigration, poverty, and socioeconomic inequality, Russell Sage Foundation, New York, NY.

Chaves, M. \& Tsitsos, W., 2001, 'Congregations and social services: What they do, how they do it, and with whom?' Nonprofit and Voluntary Sector Quarterly 30(4), 660-683. http://dx.doi.org/10.1177/0899764001304003

Chubb, K. \& Van Dijk, L., 2001, Between anger and hope: South Africa's youth and the truth and reconciliation commission, Witwatersrand University Press, Johannesburg.

Cnaan, R.A. \& Boddie, S.C., 2001, Black church outreach: Comparing how black and other congregations serve their needy neighbours, Center for Research on Religion other congregations serve their needy neighbours, Center for Research on Religion
and Urban Civil Society, University of Pennsylvania, viewed 01 June 2015, from and Urban Civil Society, University of Pennsylvania,

Comaroff, J., 1985, Body of power, spirit of resistance: The culture and history of a South African people, University of Chicago Press, Chicago, IL.
Cox, H., 1965, The secular city: Secularization and urbanization in theological perspective, Macmillan, New York, NY.

Fields, K., 1985, Revival and rebellion in colonial Central Africa, Princeton University Press, Princeton, NJ.

Fuller, R.C., 2001, Spiritual, but not religious: Understanding unchurched Americans, Oxford University Press, New York, NY. http://dx.doi. org/10.1093/0195146808.001.0001

Hyden, G., 1980, Beyond Ujamaa in Tanzania: Underdevelopment of an uncaptured peasantry, University of California Press, Berkeley, CA.

Kunreuther, F. \& Covington, P., 2006, Next shift: Beyond the nonprofit leadership crisis, Annie E. Casey Foundation, Baltimore, MD.

Laudarji, I. \& Livezey, L., 2000, 'The churches and the poor in a 'ghetto underclass' neighborhood', in L. Livezey (ed.), Public religion and urban transformation: Faith in the city, pp. 83-106, New York University Press, New York, NY.

Maharaj, B., 2009, 'Migrants and urban rights: Politics of xenophobia in South African cities', L'Espace Politique 8, 1-15. http://dx.doi.org/10.4000/espacepolitique.1402

Mamdani, M., 1996, Citizen and subject: Contemporary Africa and the legacy of late colonialism, Fountain Publishers, Kampala.

Mays, B.E. \& Nicholson, J., 1933, The Negro's church, Greenwood Publishing, New York, NY.

Nafziger, E.W., 1988, Inequality in Africa: Political elites, proletariat, peasants and the poor, Cambridge University Press, New York, NY.

Pew Forum on Religion and Public Life, 2009, 'A religious portrait of African Americans', viewed 01 June 2015, from http://www.pewforum.org/2009/01/30/a-religiousportrait-of-african-americans/

Pew Forum on Religion and Public Life, 2015, 'America's changing religious landscape', viewed 01 June 2015, from http://www.pewforum.org/2015/05/12/americaschanging-religious-landscape/

Pew Research Center, 2012, '"Nones" on the Rise', viewed 01 June 2015, from http:// www.pewforum.org/2012/10/09/nones-on-the-rise/

Raboteau, A., 1978, Slave religion: The 'invisible institution' in the antebellum South, Oxford University Press, New York, NY.

Ramphele, M., 1992, 'Social disintegration in the black community: Implications for transformation', in D. Everatt \& E. Sisulu (eds.), Black youth in crisis: Facing the future, pp. 10-29, Ravan, Johannesburg.

Resnick, D., 2013, Urban poverty and party populism in African democracies, Cambridge University Press, Cambridge. http://dx.doi.org/10.1017/СВ09781139568265

Roozen, D. \& Nieman, J. (eds.), 2005, Church, identity, and change: Theology and denominational structures in unsettled times, Eerdmans, Grand Rapids, MI.

Sennett, R., 1992, The fall of public man, W.W. Norton \& Co., New York, NY.

Simone, A., 2001, 'African migration and the remaking of inner-city Johannesburg', in A. Morris \& A. Bouillon (eds.), African immigration to South Africa: Francophone migration of the 1990s, pp. 150-170, Protea \& Ifas, Pretoria.

Smith, R.D., 1998, 'Black religious nationalism and the politics of transcendence', Journal of the American Academy of Religion 66(3), 533-547. http://dx.doi. org/10.1093/jaarel/66.3.533

Smith, R.D., 2001, 'Churches and the urban poor: Interaction and social distance', Sociology of Religion 62(3), 301-313. http://dx.doi.org/10.2307/3712352

Smith, R.D., 2003, Beyond the boundaries: Low-income residents, faith-based organizations, and neighborhood coalition building, The Annie E. Casey Foundation, Baltimore, MD.

Stark, R., 1999, 'Secularization, RIP', Sociology of Religion 60(3), 249-273. http:// dx.doi.org/10.2307/3711936

Stark, R. \& Finke, R., 2000, Acts of faith, University of California Press, Berkeley, CA.

Swartz, S., Hamilton Harding, J. \& De Lannoy, A., 2013, 'Ikasi style and the quiet violence of dreams: A critique of youth belonging in post-apartheid South Africa', in S. Swartz \& M. Arnot (eds.), Youth citizenship and the politics of belonging, in S. Swartz \& M. Arnot
Routledge, New York, NY.

Wacquant, L. \& Wilson, W.J., 1989, 'The cost of racial and class exclusion in the inner city', Annals of the American Academy of Political and Social Science 501(22), 8-25. http://dx.doi.org/10.1177/0002716289501001001

West, C., 1993, Race matters, Vintage Books, New York, NY.

Wilson, W.J., 1987, The truly disadvantaged, University of Chicago Press, Chicago, IL.

Wuthnow, R., 1990, The restructuring of American religion, Princeton University Press, Princeton, NJ.

Zuberi, T. \& Sibanda, A., 2005, 'Migration and employment', in T. Zuberi, A. Sibanda \& E. Udjo (eds.), The demography of South Africa, pp. 266-296, M. E. Sharpe, London. 